\title{
Regulation of the C/EBP $\alpha$ signaling pathway in acute myeloid leukemia (Review)
}

\author{
GUANHUA SONG $^{1}$, LIN WANG ${ }^{2}$, KEHONG BI $^{3}$ and GUOSHENG JIANG ${ }^{1}$ \\ ${ }^{1}$ Department of Hemato-Oncology, Institute of Basic Medicine, Shandong Academy of Medical Sciences, Key Laboratory \\ for Modern Medicine and Technology of Shandong Province, Key Laboratory for Rare and Uncommon Diseases, \\ Key Medical Laboratory for Tumor Immunology and Traditional Chinese Medicine Immunology of Shandong Province, \\ Jinan, Shandong 250062; ${ }^{2}$ Research Center for Medical Biotechnology, Shandong Academy of Medical Sciences, \\ Jinan, Shandong 250062; ${ }^{3}$ Department of Hematology, Qianfoshan Mountain Hospital \\ of Shandong University, Jinan, Shandong 250014, P.R. China
}

Received December 2, 2014; Accepted January 26, 2015

DOI: $10.3892 /$ or.2015.3848

\begin{abstract}
The transcription factor CCAAT/enhancer binding protein $\alpha(\mathrm{C} / \mathrm{EBP} \alpha)$, as a critical regulator of myeloid development, directs granulocyte and monocyte differentiation. Various mechanisms have been identified to explain how $\mathrm{C} / \mathrm{EBP} \alpha$ functions in patients with acute myeloid leukemia (AML). $\mathrm{C} / \mathrm{EBP} \alpha$ expression is suppressed as a result of common leukemia-associated genetic and epigenetic alterations such as AML1-ETO, RAR $\alpha$-PLZF or gene promoter methylation. Recent data have shown that ubiquitination modification also contributes to its downregulation. In addition, $10-15 \%$ of patients with AML in an intermediate cytogenetic risk subgroup were characterized by mutations of the $\mathrm{C} / \mathrm{EBP} \alpha$ gene. As a transcription factor, $\mathrm{C} / \mathrm{EBP} \alpha$ can translocate into the nucleus and further regulate a variety of genes directly or indirectly, which are all key factors for cell differentiation. This review summarizes recent reports concerning the dysregulation of $\mathrm{C} / \mathrm{EBP} \alpha$ expression at various levels in human $\mathrm{AML}$. The currently available data are persuasive evidence suggesting that impaired abnormal $\mathrm{C} / \mathrm{EBP} \alpha$ expression contributes to the development of $\mathrm{AML}$, and restoration of $\mathrm{C} / \mathrm{EBP} \alpha$ expression as well as its function represents a promising target for novel therapeutic strategies in AML.
\end{abstract}

Correspondence to: Dr Kehong Bi, Department of Hematology, Qianfoshan Mountain Hospital of Shandong University, Jingshi Road, Jinan, Shandong 250014, P.R. China

E-mail: kehongbi@126.com

Dr Guosheng Jiang, Department of Hemato-Oncology, Institute of Basic Medicine, Shandong Academy of Medical Sciences, 18877 Jingshi Road, Jinan, Shandong 250062, P.R. China

E-mail: jiangguosh@163.com

Key words: $\mathrm{C} / \mathrm{EBP} \alpha$, leukemia, differentiation, granulocyte, monocyte

\section{Contents}

1. Introduction

2. Function of $\mathrm{C} / \mathrm{EBP} \alpha$ in myeloid differentiation

3. Regulation of the $\mathrm{C} / \mathrm{EBP} \alpha$ signaling pathway

4. Conclusion

\section{Introduction}

Acute myeloid leukemia (AML) is characterized by uncontrolled proliferation of myeloid progenitors that exhibit a severe block in their ability to differentiate into mature granulocytes or macrophages (1). The transcription factor CCAAT/enhancer binding protein $\alpha(\mathrm{C} / \mathrm{EBP} \alpha)$ is a lineagespecific transcription factor in the hematopoietic system and is required for the formation of committed myeloid progenitors from multipotent precursor cells by coupling the direct transcriptional activation of myeloid-specific genes with the arrest of cell proliferation (2).

$\mathrm{C} / \mathrm{EBP} \alpha$ is specifically expressed in granulocytes, monocytes and eosinophils (3), although it is also found in hepatocytes, adipocytes and type II pneumocytes (4). Previous studies have illustrated the function of $\mathrm{C} / \mathrm{EBP} \alpha$ in hematopoiesis by promoting granulocyte and monocyte differentiation $(2,5,6)$. Studies have eported that $\mathrm{C} / \mathrm{EBP} \alpha$ expression is detectable at a low level in the hematopoietic stem cell (HSC) population, and its expression increases as these cells develop into the common myeloid progenitor (CMP) and subsequently the granulocyte-monocyte progenitor (GMP), while conditional $\mathrm{C} / \mathrm{EBP} \alpha$ deficiency in adult mice blocked the transition from CMP to GMP, resulting in reduced formation of both granulocytes and monocytes (7). Non-conditional targeted disruption of $\mathrm{C} / \mathrm{EBP} \alpha$ was found to result in a selective block in early granulocyte maturation, and these mice died at birth due to severe hypoglycemia (8). Moreover, knock-in mice with a targeted mutation in the $\mathrm{C} / \mathrm{EBP} \alpha$ basic region, which led to its dysfunction, predisposed the mice to a myeloproliferative disorder (9). However, when expressed in 32Dcl3 


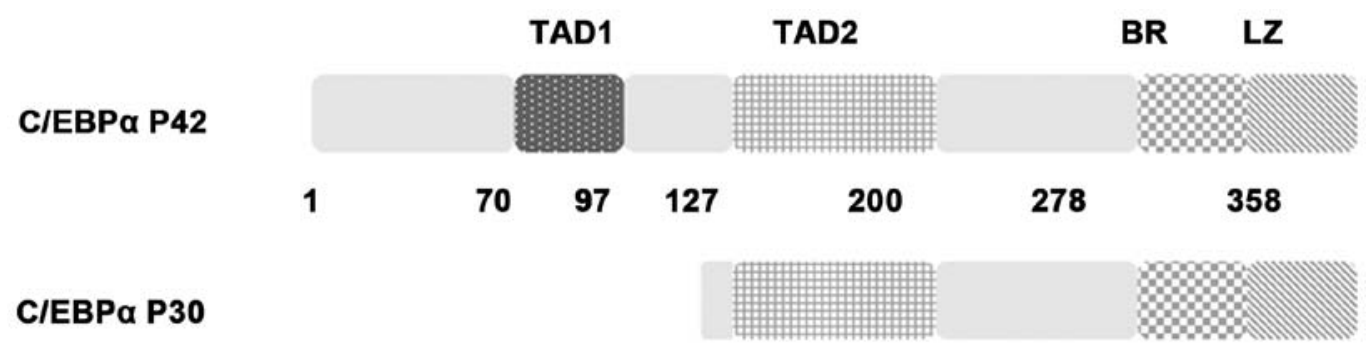

120

Figure 1. Structure of the two isoforms of $\mathrm{C} / \mathrm{EBP} \alpha . \mathrm{C} / \mathrm{EBP} \alpha, \mathrm{CCAAT} /$ enhancer binding protein $\alpha$.

cells, representative of granulocytic progenitors, exogenous $\mathrm{C} / \mathrm{EBP} \alpha$ promoted granulopoiesis (10). These studies suggest that $\mathrm{C} / \mathrm{EBP} \alpha$ is a critical regulator of myeloid development. In fact, growing evidence suggests that the function of $\mathrm{C} / \mathrm{EBP} \alpha$ is critically altered in subsets of AML patients based on various factors.

In this review, we summarized the fundamental role of $\mathrm{C} / \mathrm{EBP} \alpha$ in myeloid differentiation and the recently identified mechanisms of its activity.

\section{Function of C/EBP $\alpha$ in myeloid differentiation}

$\mathrm{C} / \mathrm{EBP} \alpha$ is a member of the basic leucine zipper (bZIP) transcription factor family, of which several members are also expressed in the myeloid lineage (e.g., C/EBP $\beta$ and $\mathrm{C} / \mathrm{EBP} \varepsilon$ ) (2). In mammals, $\mathrm{C} / \mathrm{EBP} \alpha$ is a lineage-specific transcription factor that is required for the formation of committed myeloid progenitors from multipotent precursor cells. The $\mathrm{C} / \mathrm{EBP} \alpha$ molecule contains transactivation domains (TADs) at its N-terminus and a DNA-binding and dimerization bZIP structure at its $\mathrm{C}$-terminus. Furthermore, $\mathrm{C} / \mathrm{EBP} \alpha$ is an intronless gene whose mRNA can be translated from two different AUG codons giving rise to two distinct isoforms ( $\mathrm{p} 42$ and $\mathrm{p} 30$ ). p30 lacks two $\mathrm{N}$-terminal transactivation domains that are only present on p42 (11) (Fig. 1). Unless otherwise indicated, $\mathrm{C} / \mathrm{EBP} \alpha$ represents the $\mathrm{p} 42$ isoform in the present review.

To date, numerous studies have been reported regarding the function of C/EBP $\alpha$ in AML. Firstly, genomic mutations have been detected in the $\mathrm{C} / \mathrm{EBP} \alpha$ gene in $\sim 5-14 \%$ of $\mathrm{AML}$ patients $(12,13)$. Among these mutations, $\mathrm{N}$-terminal frameshift mutations prematurely truncate the full-length $\mathrm{p} 42$ form while preserving the $\mathrm{p} 30$ form, with the latter inhibiting the remaining wild-type $\mathrm{C} / \mathrm{EBP} \alpha \mathrm{p} 42$ protein in a dominant-negative manner (12). In addition, C-terminal in-frame insertions or deletions were found to disrupt the basic zipper region, thus critically affecting DNA binding $(12,14)$, which was further illustrated by reports that the critical basic region residues of the $\mathrm{C} / \mathrm{EBP} \alpha$ protein-DNA interaction were identified by an $\mathrm{X}$-ray structure assay (14). Although there is a predominant $\mathrm{C} / \mathrm{EBP} \alpha$ mutation pattern in AML patients, the majority of AML patients always have more than one $\mathrm{C} / \mathrm{EBP} \alpha$ mutation $(13,15)$. In addition, reduced expression could disrupt the function of $\mathrm{C} / \mathrm{EBP} \alpha$ for normal hematopoiesis (16). A detailed study showed that deletion of the C/EBP $\alpha$ gene led to arrest at the CMP to GMP transition, thereby causing reduced formation of both granulocytes and monocytes (7). In addition, studies have reported that $\mathrm{C} / \mathrm{EBP} \alpha$ heterodimerizes with AP-1 proteins (C/EBP $\alpha: c-J u n$ or C/EBP $\alpha$ :-c-Fos) for preference in directing monopoiesis (17), whereas $\mathrm{C} / \mathrm{EBP} \alpha$ homodimers cooperate with NF- $\mathrm{BB}$ p50 to promote granulopoiesis (18). Regulation of macrophage and neutrophil cell fates may also be altered by the relative PU.1:C/EBP $\alpha$ ratio (19).

\section{Regulation of the C/EBP $\alpha$ signaling pathway}

As a critical factor involved in myeloid differentiation, the function of $\mathrm{C} / \mathrm{EBP} \alpha$ must be tightly regulated to maintain the differentiation homeostasis. Detailed study of the regulation of $\mathrm{C} / \mathrm{EBP} \alpha$ could also highlight the understanding of the pathological mechanisms of AML.

Regulators targeting C/EBP $\alpha$ in myeloid differentiation and leukemogenesis. Many researches have focused on the factors regulating $\mathrm{C} / \mathrm{EBP} \alpha$ expression and its functions in leukemic diseases from different aspects, such as transcriptional repression by fusion genes, ubiquitination modification and epigenetic regulation.

Among the variant translocations in AML, the $\mathrm{t}(11: 17)$ translocation is the most frequent, and renders resistance to all-trans retinoic acid (ATRA) treatment (20). After translocation, RAR $\alpha$ is fused to PLZF to produce two fusion proteins, promyelocytic eukemia zinc finger-retinoic acid receptor $\alpha$ (PLZF-RAR $\alpha$ ) and RAR $\alpha$-PLZF, both of which participate in leukemia development (21). Among them, RAR $\alpha$-PLZF recruits $\mathrm{HDAC} 1$ and causes histone $\mathrm{H} 3$ deacetylation at $\mathrm{C} / \mathrm{EBP} \alpha$ target loci, thereby decreasing the expression of $\mathrm{C} / \mathrm{EBP} \alpha$ (Fig. 2). In line with this result, HDAC inhibitors were found to restore $\mathrm{C} / \mathrm{EBP} \alpha$ expression to a modest extent (22). In addition to RAR $\alpha$-PLZF, C/EBP $\alpha$ expression could also be downregulated through direct transcriptional repression by the fusion oncoprotein AML1-ETO (23). These findings provide molecular evidence for a mechanism through which fusion proteins act as modifier oncogenes that subvert differentiation in the granulocytic lineage by inhibiting the activity of $\mathrm{C} / \mathrm{EBP} \alpha$.

Epigenic modification is envisioned as an important epigenetic mechanism that regulates the expression of myeloid-specific genes in the hematopoietic system during leukemogenesis (24). Hypermethylation of the C/EBP $\alpha$ promoter was first reported preferentially in AML-M2 patients (25). The methylation status of the C/EBP $\alpha$ gene in chronic myeloid leukemia (CML) patients was also investigated, and the data suggested that 


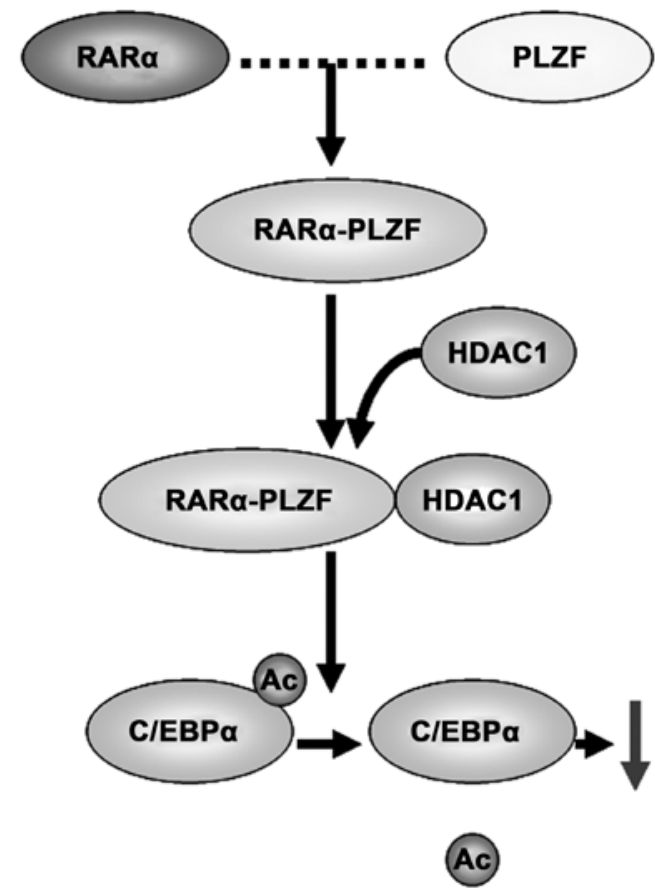

Figure 2. PLZF-RAR $\alpha$ negatively regulates $\mathrm{C} / \mathrm{EBP} \alpha$ expression. The fusion protein, PLZF-RAR $\alpha$, recruits HDAC1 and causes histone H3 deacetylation at the $\mathrm{C} / \mathrm{EBP} \alpha$ promoter, which further decreases the expression of $\mathrm{C} / \mathrm{EBP} \alpha$. PLZF-RAR $\alpha$, promyelocytic eukemia zinc finger-retinoic acid receptor $\alpha$; $\mathrm{C} / \mathrm{EBP} \alpha, \mathrm{CCAAT} / \mathrm{enhancer}$ binding protein $\alpha$.

aberrant methylation in the $\mathrm{CpG}$ island of the $\mathrm{C} / \mathrm{EBP} \alpha$ gene promoter could be a common event in CML (26). The role of EZH2 in hematopoietic development and leukemia is still controversial. Some groups suggest that EZH2 acts as a tumor suppressor in the myeloid lineage (27). However, it was also reported that ectopic expression of EZH2 causes a block in myeloid differentiation (28). A recent study found that EZH2 functions as an oncogene to block differentiation through suppressing C/EBP $\alpha$ expression. Notably, C/EBP $\alpha$ was found to be downregulated by EZH2 through methylation modification of its promoter in MA9-induced leukemia (29). Consistent with the above data, HDAC inhibitors restore $\mathrm{C} / \mathrm{EBP} \alpha$ target gene expression (22). A highly significant association was found between the frequency of $\mathrm{C} / \mathrm{EBP} \alpha$ gene epigenic modification and myeloid leukemia, while the role of $\mathrm{C} / \mathrm{EBP} \alpha$ methylation/deacetylation in the development, progression and prognosis in myeloid leukemia warrants further research.

Ubiquitination is an essential posttranslational modification for the modulation of $\mathrm{C} / \mathrm{EBP} \alpha$ activity. E3 ligases specifically targeting lysine 48 (K48)-linked ubiquitination of $\mathrm{C} / \mathrm{EBP} \alpha$ could promote the degradation of $\mathrm{C} / \mathrm{EBP} \alpha$ through the proteasome and thus terminate the downstream signaling transduction. Trib1 and Trib2 are two members of the Tribbles family that function as adapters to recruit E3 ubiquitin ligases and enhance ubiquitylation of its target protein. Consequently, Trib1 and Trib2 induce $\mathrm{C} / \mathrm{EBP} \alpha$ degradation and inhibit its function (30). E3 ubiquitin ligases, constitutively photomorphogenic 1 (COP1) (31) and E6-associated protein (E6AP) (32), were found to promote the degradation of $\mathrm{C} / \mathrm{EBP} \alpha$ by promoting its K48-linked polyubiquitination, thereby blocking myeloid differentiation of hematopoietic cells for tumorigenesis. Notably, during this process, COP1, which contains a COP1-binding motif, is recruited by Trib1 and is essential for downregulation of C/EBP $\alpha$ expression (31) (Fig. 3). However, whether any deubiquitinating enzymes exist to specifically remove K48-linked ubiquitination of $\mathrm{C} / \mathrm{EBP} \alpha$ and stabilize its expression or whether E3 ligases exist to induce K63-linked polyubiquitination to active C/EBP $\alpha$ function warrant further investigation. The answer to this question may help to elucidate the complexities of modulation of $\mathrm{C} / \mathrm{EBP} \alpha$ activity through ubiquitination/deubiquitination.

Downstream regulators targeting $C / E B P \alpha$ in myeloid differentiation and leukemogenesis. In addition to its important functions as a key target gene, several studies have demonstrated that $\mathrm{C} / \mathrm{EBP} \alpha$ may participate in leukemogenesis through regulation of a number of genes directly or indirectly.

To date, several genes have been identified as being directly regulated by C/EBP $\alpha$ in myeloid leukemia; for example, Sox4, which is critical for normal differentiation and expansion of the lymphoid and myeloid lineages $(33,34)$. In normal hematopoiesis, C/EBP $\alpha$ expression was found to be increased over the course of lineage commitment and then suppressed SOX4 expression through binding to its promoter (35). Importantly, leukemic transformation by $\mathrm{C} / \mathrm{EBP} \alpha$ mutation was partially reversed by Sox4 knockdown (36).

FMS-like tyrosine kinase-3 (FLT3) is a membranebound tyrosine kinase receptor. The interaction between the receptor FLT3 and its ligand FL led to crucial signaling during the early stages of the commitment of hematopoietic stem cells (37). Mutation or overexpression of the FLT3 gene enhanced the survival and expansion in a variety of leukemias and was associated with an unfavorable clinical outcome for AML patients (38). Kindler $e t$ al demonstrated the binding of $\mathrm{C} / \mathrm{EBP} \alpha$ in human AML on the FLT3 locus, and defined FLT3 as a direct downstream effector of $\mathrm{C} / \mathrm{EBP} \alpha$. Furthermore, they demonstrated that bi-allelic $\mathrm{C} / \mathrm{EBP} \alpha$ mutations may reduce FLT3-mediated leukemogenic signals (37), which suggests that regulation of Flt3 expression could depend on strict $\mathrm{C} / \mathrm{EBP} \alpha$ activity thresholds in AML.

In addition, glycolytic enzyme hexokinase 3 (HK3) has been defined as a glycolytic enzyme most frequently expressed in myeloid cells and represents the dominant hexokinase in granulocytes accounting for most hexokinase activity (39). By comparing gene profiles in two cohorts of $\mathrm{C} / \mathrm{EBP} \alpha$ wild-type and mutant AML patients, $\mathrm{C} / \mathrm{EBP} \alpha$ was found to directly regulate HK3 by binding to its promoter (40). Furthermore, activation of HK3 transcription was found to be dependent on $\mathrm{C} / \mathrm{EBP} \alpha$ during all-trans retinoic acid (ATRA)-mediated neutrophil differentiation of APL cells (41).

As a leukocyte-specific gene, CORO1A has been linked to the inhibition of neutrophil apoptosis, with significantly lower CORO1A mRNA expression in C/EBP $\alpha$-mutated AML $(42,43)$. Recently, C/EBP $\alpha$ was also demonstrated as a direct transcriptional regulator of CORO1A in APL and $\mathrm{C} / \mathrm{EBP} \alpha$-mutated AML patients (44).

In addition to the above-mentioned downstream effectors of $\mathrm{C} / \mathrm{EBP} \alpha-\mathrm{p} 42$, there are still several potential genes regulated by C/EBP $\alpha-p 30$, such as PIN1 and Trib2. PIN1 appears to be important in tumorigenesis since it was found to be overexpressed in many types of cancers $(45,46)$. 


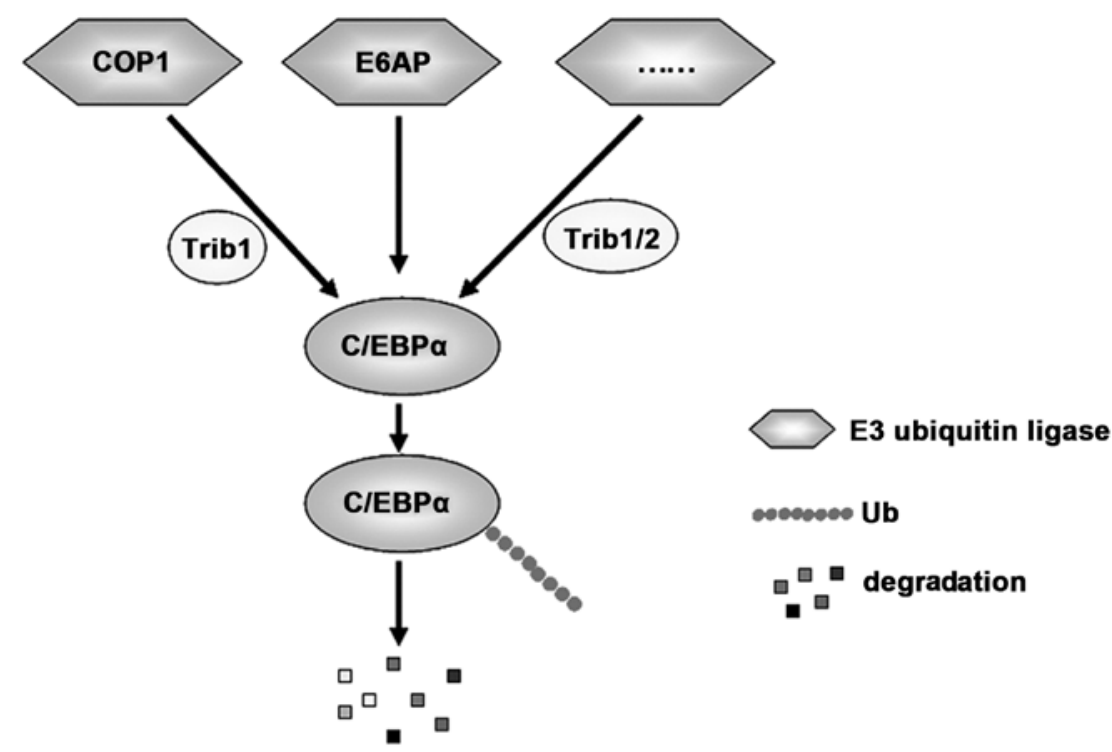

Figure 3. Regulation of C/EBP $\alpha$ by ubiquitin. E3 ubiquitin ligases, such as COP1 and E6AP, mediate C/EBP $\alpha$ proteasomal degradation, which further blocks myeloid differentiation. During this process, E3 ubiquitin ligases are recuited by Trib1 and Tirb2. C/EBP $\alpha$, CCAAT/enhancer binding protein $\alpha$; COP1, constitutively photomorphogenic 1; E6AP, E6-associated protein.

Evidence for the role of PIN1 in leukemia includes the fact that it inhibits the ubiquitination of c-Jun, which further blocks granulocyte differentiation $(46,47)$. PIN1 was detected as a target of C/EBP $\alpha-\mathrm{p} 30$ in AML, as $\mathrm{C} / \mathrm{EBP} \alpha-\mathrm{p} 30$ recruited the transcription factor E2F1 in the PIN1 promoter to elevate its expression (48). In addition to the role of Trib2 acting as an upstream effector of $\mathrm{C} / \mathrm{EBP} \alpha$ by mediating its proteasomal degradation, recent research also revealed that Trib2 can also form a feedback regulatory loop with $\mathrm{C} / \mathrm{EBP} \alpha$. In normal myeloid progenitor cells, $\mathrm{C} / \mathrm{EBP} \alpha-\mathrm{p} 42$ was found to bind to the Trib2 promoter and inhibit Trib2 activation. Conversely, C/EBP $\alpha$-p30 activated the Trib2 promoter in preleukemic cells resulting in elevated Trib2 expression, ultimately contributing to the degradation of C/EBP $\alpha-p 42$ and uncontrolled proliferation in AML (49). That is, the exact role of Trib2 depends on the activity of $\mathrm{C} / \mathrm{EBP} \alpha-\mathrm{p} 30$ or $\mathrm{C} / \mathrm{EBP} \alpha-\mathrm{p} 42$ in its specific context. However, the mechanism of the switch between these two isoforms (C/EBP $\alpha-p 30$ or $\mathrm{C} / \mathrm{EBP} \alpha-\mathrm{p} 42)$ is still unknown.

In addition to binding to the promoter of several genes to participate directly in leukemogenesis, $\mathrm{C} / \mathrm{EBP} \alpha$ also indirectly regulates certain genes over the course. For example, transcription factor krüppel-like factor 5 (KLF5), an essential factor for granulocytic differentiation, was found to have a low level in AML $(41,50)$. A study reported that KLF5 is indirectly regulated by $\mathrm{C} / \mathrm{EBP} \alpha$, with its activation dependent on C/EBP $\alpha$ during ATRA-mediated neutrophil differentiation in APL cells (41).

DAPK2 is a proapoptotic protein that is mainly expressed in hematopoietic tissue. In addition to participating in different cell death pathways $(51,52)$, Rizzi et al (53) and Fang et al (54) found a specific function for DAPK2 as an enhancer of neutrophil and erythroid differentiation. Other studies further confirmed that DAPK2 in myeloid cells is dependent on $\mathrm{C} / \mathrm{EBP} \alpha$ during granulocytic differentiation and this process seems to be indirect (55). Moreover, C/EBP $\alpha$ interferes with E2F1 transactivation of the c-Myc promoter in AML (56), which may influence proliferation and differentiation in HL-60 cells through VEGF (57) (Fig. 4).

A number of new molecular genetic abnormalities have been identified in AML in the last few decade. Further studies are needed to analyze the interrelation between them involving $\mathrm{C} / \mathrm{EBP} \alpha$, and a pivotal co-target gene would bear clinical significance.

Collaborating factors with $C / E B P \alpha$. As mentioned earlier, C/EBP $\alpha$-p30 directly activates Trib2 (49) and PIN1 (48) expression, by cooperating with E2F1 in AML. In addition, $\mathrm{C} / \mathrm{EBP} \alpha$ cooperates with several other proteins in the myeloid lineage, such as Hoxa9/Meis1. Homeobox A9 (HOXA9) is a homeodomain-containing transcription factor that plays a key role in HSC expansion and is commonly deregulated in human acute leukemias (58). Overexpression of HOXA9 always exists along with its cofactor meis homeobox 1 (MEIS1) in the pattern of Hoxa9/Meis1 in AML. Recent studies suggest that $\mathrm{C} / \mathrm{EBP} \alpha$ acts as a pioneer transcription factor in Hoxa9/ Meis1-mediated leukemogenesis through regulating its target genes, $C d k n 2 a / b$ (59) and Sox4 (60).

Previous studies have also demonstrated that $\mathrm{C} / \mathrm{EBP} \alpha$ interacts with its different binding partners, including TBP and TFIIB (basal transcription initiation factors) (61), the SWI/SNF complexes (chromatin remodeling complexes) (62), $\mathrm{Rb}$ (tumorsuppressor protein) (63), Cdk2 and Cdk4 (cyclin-dependent kinases), p21 (cyclin-dependent kinase inhibitor) (64), GABP $\alpha$ (cell cycle regulator and transcription factor) (65). All of these may play a crucial role during the process of leukemogenesis.

Small molecules targeting $C / E B P \alpha$. In search for small molecules that are able to reverse the low expression of the C/EBP $\alpha$ signature, a connectivity map was applied. This analysis predicted positive connectivity between the C/EBP $\alpha$ activation signature and histone deacetylase inhibitors. The results showed that histone deacetylase inhibitors reactivated the 

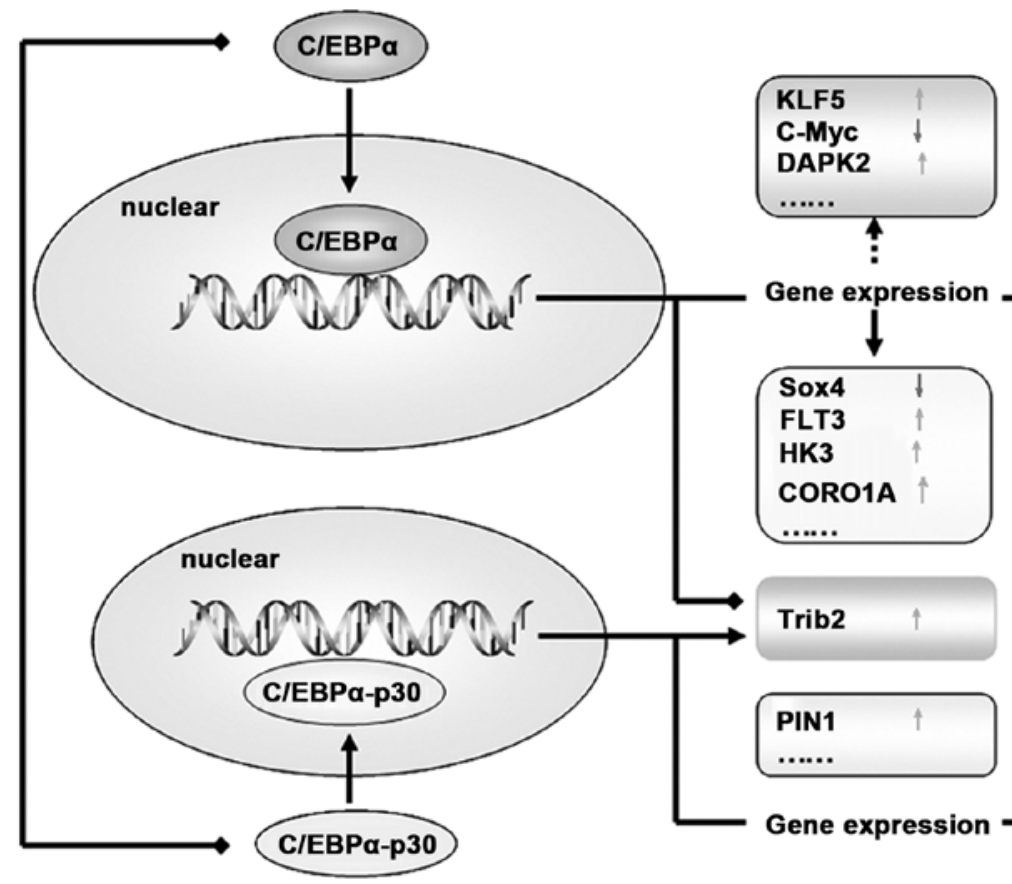

Gene expression

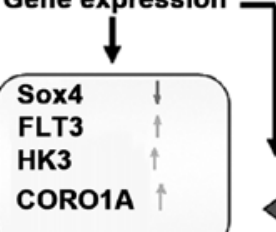

ifferentiation

.......

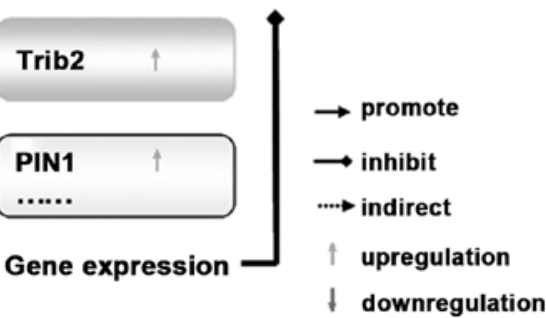

Figure 4. C/EBP $\alpha$ functions though regulation of its target genes. After its translocation into the nucleus, C/EBP $\alpha$-p 42 promotes cell differentiation by regulating the gene expression directly (such as Sox4, FLT3, HK3 and CORO1A) or indirectly (such as KLF5, DAPK2 and C-myc). In addition, C/EBP $\alpha$-p30 isoform blocks cell differentiation by targeting PIN1 and Trib2. Notably, Trib2 can be regulated by both C/EBP $\alpha-\mathrm{p} 42$ and C/EBP $\alpha-\mathrm{p} 30$ isoforms, and the switch mechanisms between them need further studies. C/EBP $\alpha$, CCAAT/enhancer binding protein $\alpha$; FLT3, FMS-like tyrosine kinase-3; HK3, hexokinase 3; KLF5, krüppel-like factor 5 .

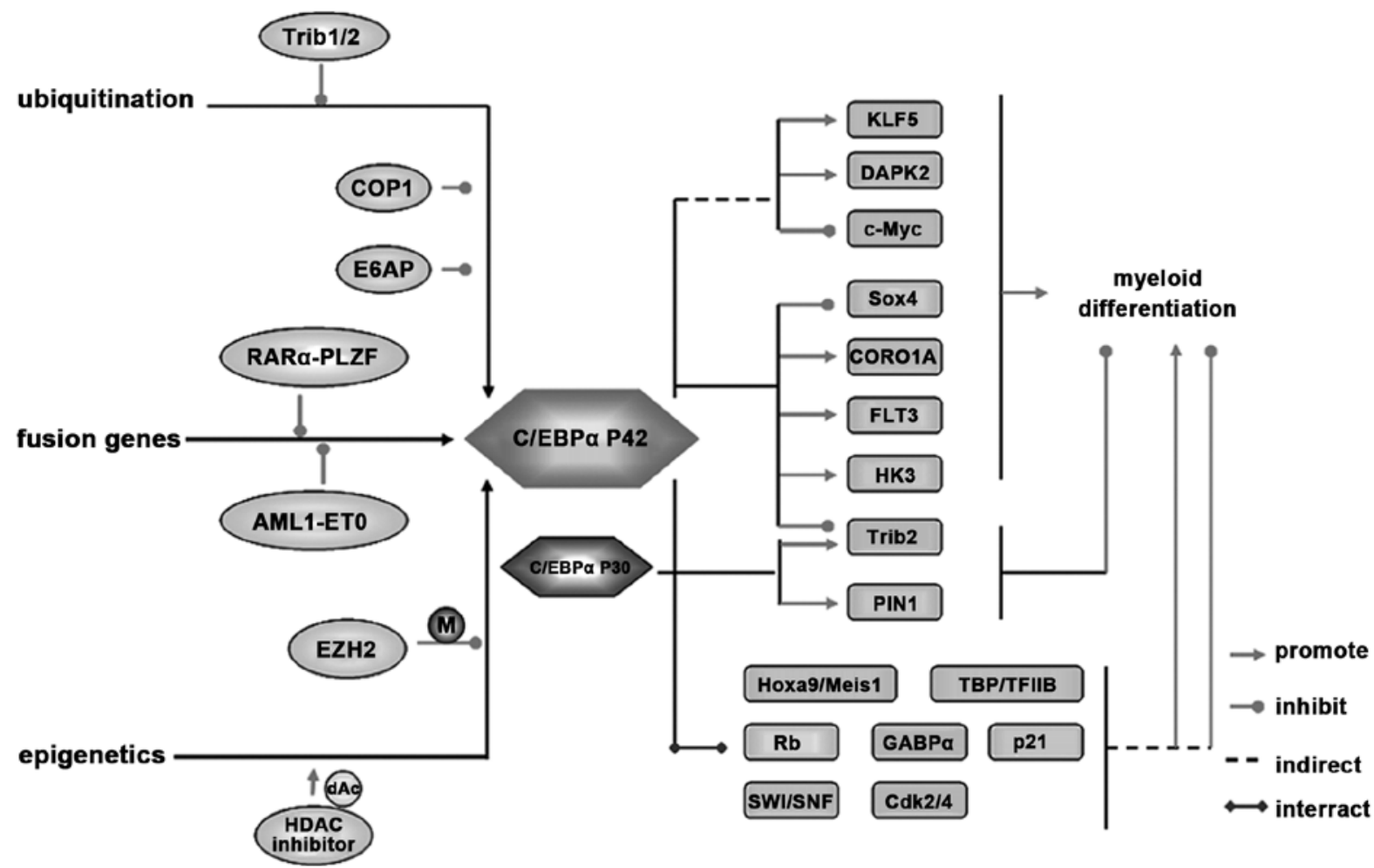

Figure 5. Schematic representation of the mechanism of $\mathrm{C} / \mathrm{EBP} \alpha$ functions during myeloid differentiation. $\mathrm{C} / \mathrm{EBP} \alpha, \mathrm{CCAAT} / \mathrm{enhancer} \mathrm{binding} \mathrm{protein} \alpha$.

expression of the $\mathrm{C} / \mathrm{EBP} \alpha$ signature and promoted granulocytic differentiation of primary samples from the C/EBP $\alpha$ dysfunctional subset harboring biallelic $\mathrm{C} / \mathrm{EBP} \alpha$ mutations (66), which indicated that HDAC inhibitors could represent a promising therapeutic approach in this particular subtype of $\operatorname{AML}(67,68)$. Cytarabine (or Ara-C) is a pyrimidine antagonist, which interferes with DNA synthesis and is used in upfront and salvage regimens for AML (69). To improve the cytotoxic activity of 
Ara-C treatment, various novel drug combinations have been explored (70,71). Recently, it was demonstrated that miR-181a could sensitize a chemotherapy-resistant HL60 cell line to Ara-C treatment (72). Zhao et al found that the C/EBP $\alpha-\mathrm{p} 30$ isoform could bind to the miR-181a-1 promoter to upregulate its expression. Furthermore, lenalidomide, a drug approved for myelodysplastic syndromes and multiple myeloma, sensitized leukemic cells to cytarabine (Ara-C) chemotherapy by enhancing translation of the C/EBP $\alpha-\mathrm{p} 30$ isoform as well as miR-181a levels (73). Additionally, Ko et al found that the methylation status of let-7a-3 was inversely correlated with the methylation status in the distal promoter region of $\mathrm{C} / \mathrm{EBP} \alpha$ in AML (74).

Therefore, it may be promising to design various small molecules targeting the $\mathrm{C} / \mathrm{EBP} \alpha$ signaling pathway for the treatment of AML.

\section{Conclusion}

In this review, we summarized the regulatory mechanisms and the functional targets of C/EBPa in AML (Fig. 5). A more detailed molecular analysis of $\mathrm{C} / \mathrm{EBP} \alpha$ will ultimately highlight a number of new oncogenes that may supplement the prognostic information obtained by conventional karyotyping. Furthermore, targeted therapies should interfere with C/EBP $\alpha$ initiating or cooperating proteins, to improve the treatment of AML. Moreover, as growing evidence implicates aberrant $\mathrm{C} / \mathrm{EBP} \alpha$ activity in a variety of diseases, including solid tumors and rheumatoid arthritis, small molecular compounds specific for $\mathrm{C} / \mathrm{EBP} \alpha$ may provide potential strategies for the therapeutic intervention of a variety of diseases.

\section{Acknowledgements}

This study was supported by grants from the National Natural Science Foundation of China (nos. 81300426, 30771103 and 81172792), the Project for Shandong Medical and Health Science and Technology Plan Project (2013WS0365), and the 'Twelfth Five-Year' National Science and Technology Support Program (2013BAI07B02).

\section{References}

1. Roe JS and Vakoc CR: C/EBP : Critical at the origin of leukemic transformation. J Exp Med 211: 1-4, 2014.

2. Rosenbauer F and Tenen DG: Transcription factors in myeloid development: Balancing differentiation with transformation. Nat Rev Immunol 7: 105-117, 2007.

3. Scott LM, Civin CI, Rorth P and Friedman AD: A novel temporal expression pattern of three C/EBP family members in differentiating myelomonocytic cells. Blood 80: 1725-1735, 1992.

4. Birkenmeier EH, Gwynn B, Howard S, Jerry J, Gordon JI, Landschulz WH and McKnight SL: Tissue-specific expression, developmental regulation, and genetic mapping of the gene encoding CCAAT/enhancer binding protein. Genes Dev 3: 1146-1156, 1989.

5. Koschmieder S, Halmos B, Levantini E and Tenen DG: Dysregulation of the C/EBPalpha differentiation pathway in human cancer. J Clin Oncol 27: 619-628, 2009.

6. Mueller BU and Pabst T: C/EBPalpha and the pathophysiology of acute myeloid leukemia. Curr Opin Hematol 13: 7-14, 2006.

7. Zhang P, Iwasaki-Arai J, Iwasaki H, et al: Enhancement of hematopoietic stem cell repopulating capacity and self-renewal in the absence of the transcription factor C/EBP alpha. Immunity 21: 853-863, 2004
8. Zhang DE, Zhang P, Wang ND, Hetherington CJ, Darlington GJ and Tenen DG: Absence of granulocyte colony-stimulating factor signaling and neutrophil development in CCAAT enhancer binding protein alpha-deficient mice. Proc Natl Acad Sci USA 94: 569-574, 1997.

9. Porse BT, Bryder D, Theilgaard-Mönch K, Hasemann MS Anderson K, Damgaard I, Jacobsen SE and Nerlov C: Loss of C/EBP alpha cell cycle control increases myeloid progenitor proliferation and transforms the neutrophil granulocyte lineage. J Exp Med 202: 85-96, 2005.

10. Wang X, Scott E, Sawyers CL and Friedman AD: C/EBPalpha bypasses granulocyte colony-stimulating factor signals to rapidly induce PU.1 gene expression, stimulate granulocytic differentiation, and limit proliferation in 32D cl3 myeloblasts. Blood 94: 560-571, 1999.

11. Bereshchenko O, Mancini E, Moore S, Bilbao D, Månsson R, Luc S, Grover A, Jacobsen SE, Bryder D and Nerlov C: Hematopoietic stem cell expansion precedes the generation of committed myeloid leukemia-initiating cells in C/EBPalpha mutant AML. Cancer Cell 16: 390-400, 2009.

12. Pabst T, Mueller BU, Zhang P, Radomska HS, Narravula S, Schnittger S, Behre G, Hiddemann W and Tenen DG: Dominantnegative mutations of CEBPA, encoding CCAAT/enhancer binding protein-alpha (C/EBPalpha), in acute myeloid leukemia. Nat Genet 27: 263-270, 2001.

13. Preudhomme C, Sagot C, Boissel N, et al: ALFA Group: Favorable prognostic significance of CEBPA mutations in patients with de novo acute myeloid leukemia: A study from the Acute Leukemia French Association (ALFA). Blood 100: 2717-2723, 2002.

14. Miller M, Shuman JD, Sebastian T, Dauter Z and Johnson PF: Structural basis for DNA recognition by the basic region leucine zipper transcription factor CCAAT/enhancer-binding protein alpha. J Biol Chem 278: 15178-15184, 2003.

15. Pabst $\mathrm{T}$ and Mueller BU: Transcriptional dysregulation during myeloid transformation in AML. Oncogene 26: 6829-6837, 2007.

16. Pabst $\mathrm{T}$ and Mueller BU: Complexity of CEBPA dysregulation in human acute myeloid leukemia. Clin Cancer Res 15: 5303-5307, 2009.

17. Cai DH, Wang D, Keefer J, Yeamans C, Hensley K and Friedman AD: C/EBP alpha:AP-1 leucine zipper heterodimers bind novel DNA elements, activate the PU.1 promoter and direct monocyte lineage commitment more potently than C/EBP alpha homodimers or AP-1. Oncogene 27: 2772-2779, 2008.

18. Wang D, Paz-Priel I and Friedman AD: NF-kappa B p50 regulates C/EBP alpha expression and inflammatory cytokine-induced neutrophil production. J Immunol 182: 5757-5762, 2009.

19. Dahl R, Walsh JC, Lancki D, Laslo P, Iyer SR, Singh H and Simon MC: Regulation of macrophage and neutrophil cell fates by the PU.1:C/EBPalpha ratio and granulocyte colony-stimulating factor. Nat Immunol 4: 1029-1036, 2003.

20. Licht JD, Chomienne C, Goy A, et al: Clinical and molecular characterization of a rare syndrome of acute promyelocytic leukemia associated with translocation $(11 ; 17)$. Blood 85: 1083-1094, 1995.

21. Chen Z, Brand NJ, Chen A, Chen SJ, Tong JH, Wang ZY, Waxman $S$ and Zelent A: Fusion between a novel Krüppel-like zinc finger gene and the retinoic acid receptor-alpha locus due to a variant $\mathrm{t}(11 ; 17)$ translocation associated with acute promyelocytic leukaemia. EMBO J 12: 1161-1167, 1993.

22. Girard N, Tremblay M, Humbert M, Grondin B, Haman A, Labrecque J, Chen B, Chen Z, Chen SJ and Hoang T: RAR $\alpha$-PLZF oncogene inhibits C/EBP $\alpha$ function in myeloid cells. Proc Natl Acad Sci USA 110: 13522-13527, 2013.

23. Pabst T, Mueller BU, Harakawa N, Schoch C, Haferlach T, Behre G, Hiddemann W, Zhang DE and Tenen DG: AML1-ETO downregulates the granulocytic differentiation factor C/EBP alpha in $\mathrm{t}(8 ; 21)$ myeloid leukemia. Nat Med 7: 444-451, 2001.

24. Baer C, Claus R, Frenzel LP, et al: Extensive promoter DNA hypermethylation and hypomethylation is associated with aberrant microRNA expression in chronic lymphocytic leukemia. Cancer Res 72: 3775-3785, 2012.

25. Chim CS, Wong AS and Kwong YL: Infrequent hypermethylation of CEBPA promotor in acute myeloid leukaemia. Br J Haematol 119: 988-990, 2002.

26. Annamaneni S, Kagita S, Gorre M, Digumarti RR, Satti V and Battini MR: Methylation status of CEBPA gene promoter in chronic myeloid leukemia. Hematology 19: 42-44, 2014

27. Nikoloski G, Langemeijer SM, Kuiper RP, et al: Somatic mutations of the histone methyltransferase gene EZH2 in myelodysplastic syndromes. Nat Genet 42: 665-667, 2010. 
28. Herrera-Merchan A, Arranz L, Ligos JM, de Molina A, Dominguez $\mathrm{O}$ and Gonzalez S: Ectopic expression of the histone methyltransferase Ezh2 in haematopoietic stem cells causes myeloproliferative disease. Nat Commun 3: 623, 2012.

29. Thiel AT, Feng Z, Pant DK, Chodosh LA and Hua X: The trithorax protein partner menin acts in tandem with EZH2 to suppress $\mathrm{C} / \mathrm{EBP} \alpha$ and differentiation in MLL-AF9 leukemia. Haematologica 98: 918-927, 2013.

30. Dedhia PH, Keeshan K, Uljon S, Xu L, Vega ME, Shestova O, Zaks-Zilberman M, Romany C, Blacklow SC and Pear WS: Differential ability of Tribbles family members to promote degradation of C/EBPalpha and induce acute myelogenous leukemia. Blood 116: 1321-1328, 2010.

31. Yoshida A, Kato JY, Nakamae I and Yoneda-Kato N: COP1 targets $\mathrm{C} / \mathrm{EBP} \alpha$ for degradation and induces acute myeloid leukemia via Tribl. Blood 122: 1750-1760, 2013.

32. Pal P, Lochab S, Kanaujiya JK, Kapoor I, Sanyal S, Behre G and Trivedi AK: E6AP, an E3 ubiquitin ligase negatively regulates granulopoiesis by targeting transcription factor $\mathrm{C} / \mathrm{EBP} \alpha$ for ubiquitin-mediated proteasome degradation. Cell Death Dis 4 e590, 2013

33. Sandoval S, Kraus C, Cho EC, et al: Sox 4 cooperates with CREB in myeloid transformation. Blood 120: 155-165, 2012.

34. Aue G, Du Y, Cleveland SM, et al: Sox4 cooperates with PU.1 haploinsufficiency in murine myeloid leukemia. Blood 118 : 4674-4681, 2011.

35. Fung TK, Leung AY and So CW: Sox4you: A new player in C/EBPa leukemia. Cancer Cell 24: 557-559, 2013.

36. Zhang H, Alberich-Jorda M, Amabile G, et al: Sox4 is a key oncogenic target in $\mathrm{C} / \mathrm{EBP} \alpha$ mutant acute myeloid leukemia. Cancer Cell 24: 575-588, 2013.

37. Kindler T, Lipka DB and Fischer T: FLT3 as a therapeutic target in AML: Still challenging after all these years. Blood 116 5089-5102, 2010

38. Kelly LM, Liu Q, Kutok JL, Williams IR, Boulton CL and Gilliland DG: FLT3 internal tandem duplication mutations associated with human acute myeloid leukemias induce myeloproliferative disease in a murine bone marrow transplant model. Blood 99: 310-318, 2002.

39. Federzoni EA, Valk PJ, Torbett BE, Haferlach T, Löwenberg B, Fey MF and Tschan MP: PU.1 is linking the glycolytic enzyme HK3 in neutrophil differentiation and survival of APL cells Blood 119: 4963-4970, 2012

40. Federzoni EA, Humbert M, Torbett BE, Behre G, Fey MF and Tschan MP: CEBPA-dependent HK3 and KLF5 expression in primary AML and during AML differentiation. Sci Rep 4: 4261 , 2014.

41. Diakiw SM, Kok CH, To LB, Lewis ID, Brown AL and D'Andrea RJ: The granulocyte-associated transcription factor Krüppel-like factor 5 is silenced by hypermethylation in acute myeloid leukemia. Leuk Res 36: 110-116, 2012.

42. Chan KT, Creed SJ and Bear JE: Unraveling the enigma: Progress towards understanding the coronin family of actin regulators Trends Cell Biol 21: 481-488, 2011.

43. Moriceau S, Kantari C, Mocek J, et al: Coronin-1 is associated with neutrophil survival and is cleaved during apoptosis: Potential implication in neutrophils from cystic fibrosis patients. J Immunol 182: 7254-7263, 2009.

44. Federzoni EA, Humbert M, Valk PJ, Behre G, Leibundgut EO, Torbett BE, Fey MF and Tschan MP: The actin-binding protein CORO1A is a novel PU.1 (SPI1)- and CEBPA-regulated gene with significantly lower expression in APL and CEBPA-mutated AML patients. Br J Haematol 160: 855-859, 2013.

45. Bao L, Kimzey A, Sauter G, Sowadski JM, Lu KP and Wang DG: Prevalent overexpression of prolyl isomerase Pin1 in human cancers. Am J Pathol 164: 1727-1737, 2004.

46. Wulf GM, Ryo A, Wulf GG, Lee SW, Niu T, Petkova V and Lu KP: Pin1 is overexpressed in breast cancer and cooperates with Ras signaling in increasing the transcriptional activity of c-Jun towards cyclin D1. EMBO J 20: 3459-3472, 2001.

47. Rinehart-Kim J, Johnston M, Birrer M and Bos T: Alterations in the gene expression profile of MCF-7 breast tumor cells in response to c-Jun. Int J Cancer 88: 180-190, 2000.

48. Pulikkan JA, Dengler V, Peer Zada AA, Kawasaki A, Geletu M, Pasalic Z, Bohlander SK, Ryo A, Tenen DG and Behre G: Elevated PIN1 expression by C/EBPalpha-p30 blocks $\mathrm{C} / \mathrm{EBPalph}$-induced granulocytic differentiation through c-Jun in AML. Leukemia 24: 914-923, 2010.
49. Rishi L, Hannon M, Salomè M, et al: Regulation of Trib2 by an E2F1-C/EBP $\alpha$ feedback loop in AML cell proliferation. Blood 123: 2389-2400, 2014.

50. Humbert M, Halter V, Shan D, Laedrach J, Leibundgut EO, Baerlocher GM, Tobler A, Fey MF and Tschan MP: Deregulated expression of Kruppel-like factors in acute myeloid leukemia. Leuk Res 35: 909-913, 2011.

51. Britschgi A, Trinh E, Rizzi M, Jenal M, Ress A, Tobler A, Fey MF, Helin K and Tschan MP: DAPK2 is a novel E2F1/KLF6 target gene involved in their proapoptotic function. Oncogene 27: 5706-5716, 2008.

52. Britschgi A, Simon HU, Tobler A, Fey MF and Tschan MP: Epigallocatechin-3-gallate induces cell death in acute myeloid leukaemia cells and supports all-trans retinoic acid-induced neutrophil differentiation via death-associated protein kinase 2 . Br J Haematol 149: 55-64, 2010.

53. Rizzi M, Tschan MP, Britschgi C, et al: The death-associated protein kinase 2 is up-regulated during normal myeloid differentiation and enhances neutrophil maturation in myeloid leukemic cells. J Leukoc Biol 81: 1599-1608, 2007.

54. Fang J, Menon M, Zhang D, Torbett B, Oxburgh L, Tschan M, Houde E and Wojchowski DM: Attenuation of EPO-dependent erythroblast formation by death-associated protein kinase-2. Blood 112: 886-890, 2008.

55. Humbert M, Federzoni EA, Britschgi A, et al: The tumor suppressor gene DAPK2 is induced by the myeloid transcription factors PU.1 and C/EBP $\alpha$ during granulocytic differentiation but repressed by PML-RAR $\alpha$ in APL. J Leukoc Biol 95: 83-93, 2014.

56. Porse BT, Pedersen TA, Xu X, Lindberg B, Wewer UM, Friis-Hansen L and Nerlov C: E2F repression by C/EBPalpha is required for adipogenesis and granulopoiesis in vivo. Cell 107: 247-258, 2001

57. Song G, Li Y, Zhang Z, et al: c-myc but not Hif-1 $\alpha$-dependent downregulation of VEGF influences the proliferation and differentiation of HL-60 cells induced by ATRA. Oncol Rep 29: 2378-2384, 2013

58. Eklund E: The role of Hox proteins in leukemogenesis: Insights into key regulatory events in hematopoiesis. Crit Rev Oncog 16: $65-76,2011$

59. Kroon E, Krosl J, Thorsteinsdottir U, Baban S, Buchberg AM and Sauvageau G: Hoxa9 transforms primary bone marrow cells through specific collaboration with Meisla but not Pbx1b. EMBO J 17: 3714-3725, 1998 .

60. Collins C, Wang J, Miao H, Bronstein J, Nawer H, Xu T, Figueroa M, Muntean AG and Hess JL: C/EBP $\alpha$ is an essential collaborator in Hoxa9/Meis1-mediated leukemogenesis. Proc Natl Acad Sci USA 111: 9899-9904, 2014.

61. Nerlov $\mathrm{C}$ and Ziff EB: CCAAT/enhancer binding protein-alpha amino acid motifs with dual TBP and TFIIB binding ability co-operate to activate transcription in both yeast and mammalian cells. EMBO J 14: 4318-4328, 1995.

62. Müller C, Calkhoven CF, Sha X and Leutz A: The CCAAT enhancer-binding protein alpha (C/EBPalpha) requires a SWI/SNF complex for proliferation arrest. J Biol Chem 279: 7353-7358, 2004.

63. Chen PL, Riley DJ, Chen Y and Lee WH: Retinoblastoma protein positively regulates terminal adipocyte differentiation through direct interaction with C/EBPs. Genes Dev 10: 2794-2804, 1996.

64. Wang H, Iakova P, Wilde M, Welm A, Goode T, Roesler WJ and Timchenko NA: C/EBPalpha arrests cell proliferation through direct inhibition of Cdk2 and Cdk4. Mol Cell 8: $817-828,2001$

65. Shimokawa T, Nunomura S, Enomoto Y and Ra C: Amino acid residues in the beta3 strand and subsequent loop of the conserved ETS domain that mediate basic leucine zipper (bZIP) recruitment and potentially distinguish functional attributes of Ets proteins. Biochem J 430: 129-139, 2010.

66. Shimokawa T, Nunomura S, Fujisawa D and Ra C: Identification of the $\mathrm{C} / \mathrm{EBP} \alpha \mathrm{C}$-terminal tail residues involved in the protein interaction with GABP and their potency in myeloid differentiation of K562 cells. Biochim Biophys Acta 1829: 1207-1217, 2013

67. Lin RJ, Nagy L, Inoue S, Shao W, Miller WH Jr and Evans RM: Role of the histone deacetylase complex in acute promyelocytic leukaemia. Nature 391: 811-814, 1998.

68. Zapotocky M, Mejstrikova E, Smetana K, Stary J, Trka J and Starkova J: Valproic acid triggers differentiation and apoptosis in AML1/ETO-positive leukemic cells specifically. Cancer Lett 319: 144-153, 2012 
69. Tallman MS, Gilliland DG and Rowe JM: Drug therapy for acute myeloid leukemia. Blood 106: 1154-1163, 2005.

70. Chen P, Aimiuwu J, Xie Z, Wei X, Liu S, Klisovic R, Marcucci G and Chan KK: Biochemical modulation of aracytidine (Ara-C) effects by GTI-2040, a ribonucleotide reductase inhibitor, in K562 human leukemia cells. AAPS J 13: 131-140, 2011.

71. Uy GL, Rettig MP, Motabi IH, et al: A phase 1/2 study of chemosensitization with the CXCR4 antagonist plerixafor in relapsed or refractory acute myeloid leukemia. Blood 119: 3917-3924, 2012.

72. Bai H, Cao Z, Deng C, Zhou L and Wang C: miR-181a sensitizes resistant leukaemia HL-60/Ara-C cells to Ara-C by inducing apoptosis. J Cancer Res Clin Oncol 138: 595-602, 2012.
73. Hickey CJ, Schwind S, Radomska HS, et al: Lenalidomidemediated enhanced translation of $\mathrm{C} / \mathrm{EBP} \alpha-\mathrm{p} 30$ protein up-regulates expression of the antileukemic microRNA-181a in acute myeloid leukemia. Blood 121: 159-169, 2013.

74. Ko YC, Fang WH, Lin TC, Hou HA, Chen CY, Tien HF and Lin LI: MicroRNA let-7a-3 gene methylation is associated with karyotyping, CEBPA promoter methylation, and survival in acute myeloid leukemia. Leuk Res 38: 625-631, 2014. 